\title{
Determination of physical properties of onions (Arka kirthiman)
}

\author{
B. Sunitha ${ }^{1}$, G. Sujatha ${ }^{1}$, B.Girish ${ }^{1}$, B. Raj KIRAN ${ }^{1 *}$ And M.V. RAMAnA ${ }^{2}$ \\ ${ }^{1}$ Department of Farm Machinery and Power, College of Agricultural Engineering, Madakasira, ANANTAPUR (DT.) (A.P.) INDIA \\ ${ }^{2}$ College of Agricultural Engineering, Madakasira, ANANTAPUR (DT.) (A.P.) INDIA \\ Email : raj.be018@gmail.com \\ *Author for Correspondence \\ Research chronicle : Received : 08.08.2015; Revised : 11.04.2016; Accepted : 25.04.2016
}

SUMMARY:

India produces about 13 per cent of total worlds onion product and ranked second after China. Onion is grown in an area of 1.0 mha in India with the production of 15.1 million tonnes and productivity of 14.2 tonnes/ hectare. Broad casting method of growing onion seeds results in the higher amount of seed rate, non-uniform distribution of seeds, poor bulb maturity and higher nutrient competition. To overcome these constraints there is a need to develop animal drawn onion seeder, which is more adaptable for small scale farmers under rainfed cultivation with reasonable cost of operation. To develop the desired seed metering unit of animal drawn seeder some of the onion seed physical properties viz., seed dimensions, weight and mechanical properties were determined. The length, width and thickness of Artthi Kirthiman onion variety were in the range of 2.50-2.95 mm, 1.75-2.24 mm and $1.33-1.53 \mathrm{~mm}$, respectively. Geometric mean diameter, spherisity, weight, bulk density, true density, porosity and angle of repose were found to be $1.96 \mathrm{~mm}, 0.71 \mathrm{~cm}, 3.69 \mathrm{~g}, 520 \mathrm{~kg} / \mathrm{m}^{3}, 975.4 \mathrm{~kg} / \mathrm{m}^{3}, 48$ per cent and $48.69^{\circ}$, respectively. The Co-efficient of static friction on glass and mild steel were found to be 0.521 and 0.556 , respectively.

KEY WORDS : Animal drawn seeder, Angle of repose, Moisture content, Static friction

How to cite this paper : Sunitha, B., Sujatha, G., Girish, B., Kiran, B. Raj and Ramana, M.V. (2016). Determination of physical properties of onions (Arka kirthiman). Internat. J. Proc. \& Post Harvest Technol., 7 (1) : 36-41. DOI: 10.15740/HAS/IJPPHT/7.1/36-41 